\title{
The Advice to Help Middle School English Underachievers out of Krashen's Affective Filter Hypothesis Learning
}

\author{
Qingmei Xu \\ Guizhou Normal University, Guiyang, China \\ 2469600270@qq.com
}

\begin{abstract}
Keywords: Krashen's the affective filter hypothesis; Emotional factors; English underachievers; Learning difficulties
\end{abstract}

\begin{abstract}
The informatization of social life and the globalization of economy make the importance of English become increasingly prominent. So, the yearning for Chinese people to learn English is stronger and stronger. However, the purposes to learn English are different, such as for travel, for work and for interests. Of course, students have to regard it as a course to learn, but more and more students are reduced to be underachievers and unable to catch up with other students' learning pace for various reasons. This article, therefore, is willing to help the English underachievers out by some suggestions, after an underachiever's case study, based on Krashen's the affective filter hypothesis.
\end{abstract}

\section{Introduction}

The aim of English curriculum on the stage of compulsory education is to cultivate students comprehensive ability to use language on the basis of language knowledge, language skills, emotional attitudes, learning strategies and cultural awareness [1]. Thereupon the reform of English is now in progress, but most of which is from the perspective of schools or teachers' teaching, to explore how to improve students' English level and ability. Yet students are the "masters" of learning, so it's necessary to talk about how to regulate students themselves and regain interests in English to learn it well from the point of view of learners, on account of internal factors deciding the nature of a thing and its developmental direction. In fact, there are many reasons to influence the learning effect. So, we should not only consider the external learning and students' intelligence, but also learners' affective factors, which have been paid much attention by scholars and experts since the middle of last century. A famous American linguist Stephen Krashen in the 1980s, put forward the affective filter hypothesis, which analyzes the relationship between language learning and learners' affective factors [2]. This paper will offer some advice to help underachievers adjust themselves out of learning difficulties as soon as possible from the perspective of the Krashen's affective filter hypothesis, after analyzing an English underachiever's case.

\section{Brief Introduction of the Affective Filter Hypothesis}

Language learning is the process from language input to language intake. But Krashen(1982) presented that learners can not intake what they input, owing to emotional factors, which means the emotion plays a "filter" role in the course of learning [2]. Ding Haiyan(2003), meanwhile, treated affective factors as a valve, its switch determining the degree of a learner's intake [3]. When the valve is closed, the language input is difficult to enter into the brain mechanism of language acquisition, which, thus, affects the learners' learning ability. But the switch degree of "valve" totally differs from person to person. That is to say, the extent of affectives' filtering effect for learning English is different for different persons. Krashen believes that emotional factors include learning motivation, self-confidence, anxiety and the like [2]. Xiaomei Wang put the affective filter hypothesis into teaching practice, and proved it is beneficial for students to improve their English writing [4]. If the learning motivation and self-confidence are stronger, and the anxiety is weaker, the emotional filtering effect will be weaker, so that learners can get more understandable input and effective knowledge. 


\section{Definition of Underachievers}

Xia Ding(2006) concluded that the domestic and foreign experts tend to define underachievers from three aspects: one is the qualitative definition according to students developmental condition of knowledge and ability; the second one is to judge by quantification based on the standard of examination results; the third one is the combination of the first two, the qualitative and quantitative research [5]. While Jie $\mathrm{Su}(2016)$ considered that the students who fail two of three subjects(Chinese, mathematics and English) are defined as underachievers [6]. And this paper mainly talks about the underachievers who fail in English.

It would be self-evident that there are many reasons leading to difficulty in learning English and, generally speaking, students with learning difficulties in English can be divided in five types: the weakness of learning foundation, the lack of learning motivation, the psychological trauma result from learning, ineffective learning methods and family difficulties. Although underachievers can be grouped into different types based on various reasons, they have similar psychological features such as, the ambiguity of learning objectives, the shortage of learning autonomy, the decentralization of attention in class and the passive psychology of anxiety inferiority and sluggishness, as Jie $\mathrm{Su}(2016)$ found based on questionnaires, which obviously coincide with the affective factors(learning motivation, confidence and anxiety) provided by Krashen. So it can be sure that part psychological features of underachievers are the affective "filter" for students learning English.

\section{A Case Study}

Basic Information About the Case. One of my students, named Shunli Zhao, a boy, had never got English training before entering into junior high school. So, he was an English underachiever, in the beginning, with 26 grades in the first exam, compared with other students who attained three-year English learning in primary school. When meeting his exam paper, I couldn't believe what I saw, but had to accept the fact, and took actions to excavate more details about the boy by calling his father. After the talk with his family, I began to pay much attention to him in class and after class.

The Analysis and Reflection of the Case. During class, it went without saying that he refused to take part in group activities and was afraid to voice his opinions, just for fear of being in derision, which demonstrated that he learned English with deep anxiety and without self-confidence. Thus, it's normal for him to get low points in exam. At that moment, the first what he should solve is to adjust his emotional elements, that is, affective factors. But how? Ema Ushioda held that common sense suggests that the high achievers of this world must have motivation, defined as it moves a person to take certain choices, to engage in action, and to persist in action [7].

It's universally acknowledged that students, the center of learning, also need to get some assistance from others to help themselves out of mental difficulties with motivation in learning English. Hence, after that, he would receive some encouragement from the whole classmates at any moment in class, on account of his little progress, no matter about scores or other behaviors revealing his positive attitude for learning English. Gradually, he started to find back his confidence and learning motivation in English and actively opened his mouth to teachers and parents to pour out his confusion about English. Of course, under the help of teachers, parents and classmates, he got great grades in entrance examination for secondary school finally, although failing many times during the three-year junior high school life, in that entering a learning environment with a low level of anxiety, he was much more likely to become successful language learners than those who do not [8]. Based on this case, it's easily learned that only if they are confident in themselves, reducing the hindering function of affective "filter", can they have a happy ending no matter how many times failures. Therefore, it's in sore need of some suggestions to favor underachievers out of difficulties in mentality and study.

\section{The Advice for English Underachievers Based on Affective Factors}

Owing to a series of reasons, some students learn English more and more difficult, and fail in 
English again and again, which gradually step away their learning motivation and self-confidence, and their anxiety is stronger and stronger under the pressure of teachers and parents, all of which make students themselves be in a dilemma between continuing to study and stopping learning. Leslis(1987) thought that psychological characteristics of underachievers are the intrinsic factors, which emphasize the role of individual learners, that is, their own will [9]. At the moment of dilemma, the learners are willing to get mental comfort by means of all sorts of excuses for them not to learn, for example, they tell themselves that they will not take up any jobs related to English. The students with the idea above are sure to become underachievers finally.

Adjust Learning Attitude and Recognize the Importance of Learning English. It is universally acknowledged that attitude deciding everything, a positive attitude will help students get rid of the idea of escaping, in order to dispel difficulties or setbacks and find the source of failure. As a student, it's seriously important to adjust learning attitude and recognize the importance of learning English. English, one of communication tools, can help to broaden our horizons to understand the wonder brought by English, such as the charm of English songs or movies, the beauty of world masterpieces, and the wide knowledge within a certain field. On the other hand, the Chinese status in the world is increasingly prominent, so it's normal to use English to communicate in our daily life in order to get in touch with foreign countries. In fact, a positive attitude, enhancing self-confidence and reducing anxiety, can promote students be willing to learn.

Make Plans and Develop a Good Habit of Self-discipline. Forewarned is forearmed. As it is known, the plan is the blueprint of achieving the goal, which can help students learn English, a complex language system, step by step and finishing just a simple thing as planned can reinforce learners' self-efficacy. Gradually, the stronger one's self-efficacy is, the stronger one's confidence. At the same time, doing things depending on plans can give support to form a good habit of self-discipline, which is the basic ability for the ones who eager to get success. Therefore, there is no doubt that it is necessary for English underachievers to make learning arrangements to develop the habit of self-discipline, in order to get out of "learning difficulties" as quickly as possible.

Establish a Good Relationship with Teachers and Classmates Positively. A good relationship with teachers and classmates can enable students to obtain a positive experience and life attitude, which is not only conducive to the mental health of students, but also promotes the harmonious development of a learner's personality. Only communicating with people holding a positive attitude and outlook on life and values, can foster learners to arrange and expect future life which enable learners to have the motivation to learn English, bringing hope for underachievers to get separated from "learning setbacks".

Accept Psychological Consulting and Training Positively. Besides self-regulation, it's a good choice for underachievers to make use of external help, such as psychological consulting, to get rid of "learning difficulties". Also, in almost every school, there is specialized consulting service for students, a place for students to express their psychological ideas and difficulties faced currently, for the purpose of diversifying underachievers' mood and anxiety. In addition, some training, such as participating a summer camp or sports, also can let students vent their emotions, steel mental toughness and enhance self-confidence. And Xuesheng Zhang(1911) found that rock climbing is effective to enhance students confidence based on the questionnaire survey for college students [10] .

Analyze "Self" Again and Find Their Own Merits. It's the moment for underachievers to make an analysis for themselves again, aiming at finding their own virtues, after communicating with teachers an psychological experts and forming a good manner of self-discipline. Zhen Liu and her partners(2012) got a conclusion that making full use of the role of "self", will achieve the desired level of English and ability [11]. Dornyei(2001) also advised to put "self" in the key position for behavior and motivation research [12]. Once students have a clear analysis of "themselves" and find out their own merits, their self-confidence will be improved, While the function of affective "filter" will become weak, and then, it's not just a dream for underachievers out of "learning difficulties". 


\section{Conclusion}

The affective factors(learning motivation, self-confidence and anxiety) put forward by the Krashen's affective filter hypothesis play a "filter" role in the process of learning English from language "input" to language "intake". Despite various factors influencing students' English learning, it's necessary to pay close attention to the affective filter effect for underachievers learning English. Meanwhile, for students, the "masters" of learning, it's essential to defect from "underachievers" by themselves as quickly as possible.

In fact, emotions are one's internal activities, not easy to be observed in daily life, and it seems a little unilateral to mention just one case in this article, but it, from the underachievers' point of view, still would like to give some suggestions, according to the affective factors proposed by Krashen, for the purpose of helping the underachievers in English out of "learning difficulties".

\section{References}

[1] Ministry of Education, Compulsory Education English Curriculum Standards, 2011 ed, (Beijing Normal University Press, Beijing 2011). (in Chinese)

[2] H.C. Dulay, M.K. Burt, S.D. Krashen, Language Two, (Oxford University Press, New York 1982).

[3] H. Y. Ding, The impact of Krashen's Affective Filtering Hypothesis on adult English acquisition, J. Jiangnan University, 10 (2000).(in Chinese)

[4] X. M. Wang, English writing teaching, J. Theory and Practice of Education, 37(2017)56-57.(in Chinese)

[5] X. Ding, The study for reasons and countermeasures for underachievers of junior high school in the country, (MS., Northeast Normal University, Changchun 2006).

[6] J. Su, Comparative study on psychological characteristics of underachievers and achievers in study, J. Modern Primary and Secondary Education, 4 (2016).(in Chinese)

[7] E. Ushioda, Motivation and good language learners, in: Carol Griffiths, Lessons from Good Language Learners, Cambridge University Press, 2008, pp.19-32.

[8] H. C. K. Lin, C. J. Chao and T. C. Huang, From a perspective on foreign language learning anxiety to develop affective tutoring system, J. Education Technology Research and Development, 65(2015)727-747.

[9] L. Dickinson, Self-instruction in Language Learning, (Cambridge University Press, England 1987).

[10]X. S. Zhang, The experimental study on rock climbing movement to improve the level of self-confidence of college students, J. Physical Education, 9 (2011).(in Chinese)

[11]Z. Liu, X. J. Yao and S. F. Hu, Structural analysis of second language self, anxiety and motivation learning behavior, J. Foreign Language, 6 (2012) 153. (in Chinese)

[12]Z. Dornyei, Teaching and Researching Motivation, (Longman Pearson Education Ltd, Harlow 2001). 